\title{
PENGARUH KOMUNIKASI DAN BUDAYA ORGANISASI TERHADAP KINERJA KARYAWAN PADA PT. ABADI LESTARI MANDIRI PALEMBANG Nina Fitriana ${ }^{1}$, Frecilia Nanda Melvina ${ }^{2}$
}

1, 2, Dosen jurusan Manajemen, Universitas Tridinanti, Sumatera Selatan

${ }^{2)}$ Email : freciliananda@univ-tridinanti.ac.id

\section{Submitted: \\ $06 / 01 / 2021$ \\ Revised: \\ $25 / 05 / 2021$ \\ Accepted: \\ $27 / 06 / 2021$ \\ Online-Published: \\ $30 / 06 / 2021$}

INFORMASI ARTIKEL

\begin{abstract}
ABSTRAK
Penelitian ini bertujuan untuk mengetahui pengaruh komunikasi dan budaya organisasi terhadap kinerja karyawan PT. Abadi Lestari Mandiri Palembang, baik secara parsial maupun simultan. Metode yang digunakan adalah metode deskriptif dengan analisis regresi berganda. Populasi dalam penelitian ini adalah karyawan pada PT. Abadi Lestari Mandiri Palembang yang berjumlah 45 orang.

Hasil penelitian ini menunjukkan bahwa secara simultan komunikasi dan budaya organisasi berpengaruh terhadap kinerja karyawan PT. Abadi Lestari Mandiri. Variabel budaya organisasi memiliki pengaruh yang dominan terhadap kinerja PT. Abadi Lestari Mandiri Palembang dengan nilai 0,836\%. Kata Kunci : Komunikasi, Budaya Organisasi, Kinerja Karyawan.
\end{abstract}

\begin{abstract}
ABSTRACK
This study aims to determine the influence of communication and organizational culture on the performance of employees of PT. Abadi Lestari Mandiri Palembang, either partially or simultaneously.The method used is a descriptive method with multiple regression analysis. The population in this study were employees at PT. Abadi Lestari Mandiri Palembang, amounting to 45 people.

The results of this study indicate that simultaneously communication and organizational culture have an influence on the performance of the employees of PT. Abadi Lestari Mandiri. Organizational culture variables have a dominant influence on the performance of PT. Abadi Lestari Mandiri Palembang with a value of $0.836 \%$.

Keyword: Communication, Organizational Culture, Performance of Employees.
\end{abstract}

\section{A. PENDAHULUAN}

Keberhasilan pengelolaan sumber daya manusia tidak lepas dari komunikasi dan budaya organisasi serta pemahaman atas fungsinya terhadap faktor-faktor yang mempengaruhinya. Adanya komunikasi dalam suatu organisasi akan menjadikan karyawan lebih termotivasi dan jelas arah tujuan yang ingin dicapai.

Menurut Veitzal Rivai (2014: 350) komunikasi diartikan sebagai proses penyampaian informasi atau pengiriman kepada penerima informasi. Dalam hal ini penerima informasi harus memahami isi informasi yang diterima, sebaliknya apabila penerima informasi tidak memahami isi informasi yang diberikan oleh pemberi informasi, berarti tidak terjadi komunikasi yang efektif yang pada akhirnya dapat menimbulkan konflik. Komunikasi dalam suatu organisasi lahir dari kebiasaan, perilaku, dan nilai-nilai dari seorang pemimpin yang mengatur aktifitas didalam organisasi tersebut. Penerapan komunikasi yang berkaitan dengan sistem kerja karyawan sangat dipengaruhi oleh sikap dari pimpinan perusahaan, sebab setiap karyawan membutuhkan kenyamanan, ketegasan serta fasilitas yang memadai yang dapat menunjang kinerja karyawan.

Budaya organisasi sangat diperlukan oleh setiap perusahaan yang selalu dikembangkan dan disesuaikan dengan perubahan lingkungan organisasi. Lingkungan organisasi terdiri dari sumber daya manusia dengan latar belakang dan tingkatan yang berbeda. Dengan demikian, perubahan budaya organisasi dilakukan terlebih dahulu melalui pengubahan pola pikir segenap sumber daya manusia didalam organisasi. Definisi budaya organisasi menurut Schein Edgar (2014) adalah pola asumsi dasar bersama yang dipelajari oleh kelompok saat memecahkan masalah-masalah adaptasi 
ekstern dan integrasi internal yang telah berfungsi dengan cukup baik untuk bisa dianggap absah dan untuk bisa diajarkan kepada anggota kelompok baru sebagai cara yang benar untuk menerima sesuatu, berfikir dan merasakan dalam hubungan dengan masalah-masalah tersebut.

Budaya merupakan bauran kompleks dari asumsi, tingkah laku, cerita, mitos, metafora, dan ide yang lain yang digabungkan menjadi satu untuk menentukan apa arti bekerja dalam suatu organisasi tertentu. Budaya organisasi juga memiliki dampak pada efisiensi organisasi. Budaya organisasi yang kuat dapat membentuk identitas perusahaan yang memberikan keunggulan kompetitif dibandingkan dengan perusahaan lainnya. Budaya organisasi juga memiliki pengaruh terhadap perilaku individu sesuai dengan tujuan organisasi, karena itu banyak manajemen mengambil tindakan untuk membentuk dan mengubah gaya budaya organisasi yang disesuaikan dengan kondisi terkini. Sebab, budaya organisasi yang dinilai baik pada waktu lalu mungkin sudah tidak relevan pada kondisi dan perubahan yang terjadi saat ini.

Menurut Anwar Prabu Mangkunegara (2013:67) kinerja adalah hasil kerja secara kualitas dan kuantitas yang dicapai oleh seorang pegawai dalam melaksanakan tugasnya sesuai dengan tanggung jawab yang diberikan kepadanya.

Selanjutnya, karyawan menjadi berkualitas apabila komunikasinya yang terjadi di perusahaan berjalan baik dan lancar. Sehingga dapat mempengaruhi penerapan budaya organisasi yang efektif, serta agar kinerja karyawan pun meningkat.

Namun, komunikasi dan budaya organisasi di PT. Abadi Lestari Mandiri tidak terlaksana dengan baik. Terlihat dari adanya:

kurangnya komunikasi dua arah antar karyawan, budaya organisasi seperti kedisplinan tidak diterapkan dengan baik, kinerja menurun, seperti tugas-tugas yang tidak dikerjakan tepat waktu. Selain itu karyawan juga membutuhkan adanya kegiatan-kegiatan yang dapat mempererat tali persaudaraan antar karyawan seperti kegiatan gathering.

Berdasarkan uraian diatas, maka peneliti merasa tertarik untuk melakukan penelitian pada PT. Abadi Lestari Mandiri Palembang. Penelitian ini yang berjudul "Pengaruh Komunikasi dan Budaya Organisasi Terhadap Kinerja PT. Abadi Lestari Mandiri Palembang"

\section{Rumusan masalah}

Berdasarkan latar belakang masalah tersebut maka dapat dirumuskan permasalahan sebagai berikut:

1. Apakah pengaruh komunikasi terhadap kinerja karyawan pada PT. Abadi Lestari Mandiri Palembang secara parsial?

2. Apakah pengaruh budaya organisasi terhadap kinerja karyawan pada PT. Abadi Lestari Mandiri Palembang secara parsial?

3. Apakah pengaruh komunikasi dan budaya organisasi terhadap kinerja karyawan pada PT. Abadi Lestari Mandiri Palembang secara simultan?

\section{Tujuan Penelitian}

Adapun tujuan dari penelitian ini adalah sebagai berikut :

1. Untuk mengetahui komunikasi terhadap kinerja karyawan pada PT. Abadi Lestari Mandiri Palembang secara parsial.

2. Untuk mengetahui pengaruh budaya organisasi terhadap kinerja karyawan pada PT. Abadi Lestari Mandiri Palembang secara parsial.

3. Untuk mengetahui pengaruh komunikasi dan budaya organisasi terhadap kinerja karyawan pada PT. Abadi Lestari Mandiri Palembang secara simultan.

\section{Tinjauan Pustaka \\ Pengertian Komunikasi}

Komunikasi memiliki arti yang sangat penting bagi manusia, karena tanpa komunikasi tidak akan terjadi interaksi dan tidak akan terjadi saling tukar pengetahuan dan pengalaman apalagi untuk melakukan kerja sama dalam rangka mencapai tujuan bersama. Komunikasi sangat penting bagi seluruh fungsi perusahaan, karena sistem 
operasional dan manajemen digerakakan oleh komunikasi (Goris, 2016).

\section{Dimensi Komunikasi}

Dimensi-dimensi dalam proses komunikasi (Deddy Mulyana, 2013:69) diantaranya:

1. Dimensi isi

Dimensi isi disandi secara verbal dan menunjukan muatan (isi) komunikasi, yaitu apa yang dikatakan. Dalam komunikasi, dimensi isi merujuk pada isi pesan.

2. Dimensi hubungan

Dimensi hubungan menunjukan dan mengisyaratkan bagaimana proses komunikasi antar satu sama lain dan bagaimana seharusnya pesan tersebut disampaikan

3. Dimensi Arah

Dimensi arah dalam komunikasi ini memiliki dua jenis, yaitu komunikasi satu arah dan komunikasi dua arah, komunikasi satu arah merupakan bentuk arah komunikasi dimana hanya terjadi pemberian informasi dari seseorang kepada lawan bicaranya tanpa ada pemberian informasi balik, sedangkan komunikasi dua arah merupakan komunikasi dimana seseorang memberikan informasi kepada lawan bicara dan lawan bicaranya juga memberikan informasi kepada lawan tersebut, sehingga terdapat pertukaran informasi diantara keduanya.

\section{Indikator Komunikasi}

Menurut Suranto Aw (2011). Komunikasi dikatakan efektif apabila dalam suatu proses komunikasi itu, pesan yang disampaikan seorang komunikator dapat diterima dan dimengerti oleh komunikan, persis seperti yang dikehen-daki oleh komunikator, dengan demikian, dalam komunikasi itu komunikator berhasil menyampaikan pesan yang dimaksudkannya, sedang komunikan berhasil menerima dan memahaminya.

Efektifnya sebuah komunikasi adalah jika pesan yang dikirim memberikan pengaruh terhadap komunikan, artinya bahwa informasiyang disampaikan dapat diterima dengan baikn sehinggamenimbulkan respon atau umpan balik dari penerimanya. Seperti contohnya: adanya tindakan, hubungan yang makin baik dan pengaruh pada sikap.
Menurt Suranto AW (2011) ada beberapa indikator komunikasi efektif, ialah:

1. Pemahaman

Ialah kemampuan memahami pesan secara cermat sebagaimana dimaksudkan oleh komunikator. Tujuan daro komunikasi adalah terjadinya pengertian bersama, dan untuk sampai pada tujuan, maka seseorang komunikator maupun komunikan harus sama-sama saling mengerti fungsinya masing-masing. Komunikator mampu menyampaikan pesan sedangkan komunikan mampu menerima pesan yang disampaikan oleh komunikator.

2. Kesenangan

Apabila proses komunikasi itu selain berhasil menyampaikan informasi, juga dapat berlangsung dalam suasana yang menyenangkan kedua belah pihak. Suasana yang lebih rilex dan menyenangkan akan lebih enak untuk berinteraksi bila dibandingkan dengan suasana yang tegang. Karena komukasi bersifat fleksibel. Dengan adanya suasana semacam itu, maka akan timbul kesan yang menarik.

3. Pengaruh pada sikap

Tujuan berkomunikasi adalah mempengaruhi sikap. Jika dengan berkomunikasi dengan orang lain, kemudian terjadi perubahan pada perilakunya, maka komunikasi yang terjadi adalah efektif, dan jika tidak ada perubahan pada sikap seseorang, maka komunikasi tersebut tidak efektif.

4. Hubungan yang makin baik

Bahwa dalam proses komunikasi yang efektif secara tidak sengaja meningkatkan kadar hubungan interpersonal. Seringkali jika orang telah memiliki persepsi yang sama, kemiripan karakter,cocok, dengan sendirinya hubungan akan terjadi dengan baik.

5. Tindakan

Komunikasi akan efektif jika kedua belah pihak setelah berkomunikasi terdapat adanya sebuah tindakan. Alexis Tan mengemukakan bahwa. Perlu ada daya tarik dengan similarity (kesamaan), familiarity (keakraban) dan proximility (kesukaan). Seseorang biasanya akan cenderung lebih tertarik dengan orang lainkarena memiliki kesamaan (sama 
hobi, sama sifat), keakraban (keluarga, teman karib), dan kesukaan. Dengan kondisi seperti itu orang tidak merasa sungkan untuk berbicara, yakni menceritakan masalah hidupnya secara jujur tanpa adanya kecanggungan berkomunikasi diantara keduanya. Jika sudah demikian, maka antara satu dengan yang lainya akan saling mempengaruhi dan dengan sendirinya komunikasi akan berlangsung secara efektif. Komunikasi efektif menuntut kepekaan seseorang dalam situasi dan kondisi yang ada, bahkan telah banyak kegagalan organisasi dikaitkan dengan komunikasi yang buruk. Masalah yang paling sulit dalam komunikasi adalah bagaimana cara mendapatkan perhatian dari para pendengar untuk memastikan bahwa mereka mendengarkan.

\section{Pengertian Budaya Organisasi}

Menurut Emron Edison, Yohny Anwar dan Imas Komariah (2016:119) Budaya organisasi merupakan hasil dari suatu proses mencairkan dan meleburkan gaya budaya dan atau perilaku tiap individu yang dibawa sebelumnya kedalam sebuah norma-norma dan filosofi yang baru, yang memiliki energi serta kebanggaan kelompok dalam menghadapi sesuatu dan tujuan tertentu. Sedangkan kekuatan dari budaya organisasi itu sendiri sangat bergantung pada nilai-nilai konstruksi yang dibangun dan memengaruhi cara mereka bertindak.

\section{Dimensi dan Indikator Budaya Organisasi}

Dimensi dan indikator budaya organisasi diuraikan sebagai berikut menurut Edison (2016: 131) :

1. Kesadaran diri. Anggota organisasi dengan kesadarannya bekerja untuk mendapatkan kepuasan dari pekerjaan mereka, mengembangkan diri, menaati aturan, serta menawarkan produk-produk berkualitas dan layanan tinggi.

2. Keagresifan. Anggota organisasi menetapkan tujuan yang menantang tapi realistis. Mereka menetapkan rencana kerja dan strategi untuk mencapai tujuan tersebut serta mengejarnya dengan antusias.
3. Kepribadian. Anggota bersikap saling menghormati, ramah, terbuka, dan peka terhadap kepuasan kelompok serta sangat memperhatikan aspek-aspek kepuasaan pelanggan, baik pelanggan internal maupun eksternal.

4. Performa. Anggota organisasi memiliki nilai kreativitas, memenuhi kuantitas, mutu, dan efisien.

5. Orientasi tim. Anggota organisasi melakukan kerjasama yang baik serta melakukan komunikasi dan koordinasi yang efektif dengan keterlibatan aktif para anggota, yang pada gilirannya mendapatkan hasil kepuasan tinggi serta budaya bersama.

\section{Pengertian Kinerja}

Menurut Anwar Prabu Mangkunegara (2013 : 67) kinerja adalah hasil kerja secara kualitas dan kuantitas yang dicapai oleh seorang pegawai dalam melaksanakan tugasnya sesuai dengan tanggung jawab yang diberikan kepadanya. Sedangkan Veitzhal Rivai (2011 : 554) mengemukakan bahwa kinerja merupakan perilaku nyata yang ditampilkan setiap orang sebagai prestasi kerja yang dihasilkan oleh karyawan sesuai dengan perannya dalam perusahaan.

\section{Dimensi Kinerja dan Indikator Kinerja}

Berdasarkan pendapat Simamora (Mangkunegara, 2009: 14) yang mengatakan bahwa kinerja (performance) dipengaruhi oleh tiga faktor atau dimensi, yaitu:

1. Dimensi individual (atribut individu).

2. Dimensi psikologis (upaya kerja atau work effort).

3. Dimensi organisasi (dukungan organisasi).

Dengan pendapat tersebut, dirangkai suatu definisi konseptual variabel penelitian bahwa kinerja adalah sebagai hasil - hasil yang dicapai oleh individu dalam melaksanakan tugas yang telah diembankan kepadanya, baik dari segi kualitas maupun kuantitas maupun kualitas berdasarkan standar kerja yang telah ditentukan, yang meliputi atribut individu, upaya kerja (work effort) dan dukungan organisasi. 


\section{Hipotesis}

Berdasarkan kerangka pemikiran yang dijelaskan di atas, maka hipotesis penelitian ini adalah:

1. Diduga terdapat pengaruh positif dan signifikan komunikasi terhadap kinerja karyawan pada PT. Abadi Lestari Mandiri Palembang secara parsial.

2. Diduga terdapat pengaruh positif dan signifikan pengaruh budaya organisasi terhadap kinerja karyawan pada PT. Abadi Lestari Mandiri Palembang secara parsial.

3. Diduga terdapat pengaruh positif dan signifikan pengaruh komunikasi dan budaya organisasi terhadap kinerja karyawan pada PT. Abadi Lestari Mandiri Palembang secara simultan.

\section{B. METODE PENELITIAN}

\section{Populasi dan Teknik Pengumpulan Data}

Menurut Arikunto (2012:173)

Populasi adalah keseluruhan subjek penelitian. Populasi dalam penelitian ini adalah 45 orang yang merupakan seluruh karyawan PT. Abadi Lestari Mandiri.

\section{Tabel 1 Populasi Karyawan}

\begin{tabular}{|c|c|}
\hline $\begin{array}{c}\text { Jabatan } \\
\text { Karyawan }\end{array}$ & Jumlah (Orang) \\
\hline $\begin{array}{c}\text { Staff } \\
\text { Administrasi }\end{array}$ & 8 \\
\hline $\begin{array}{c}\text { Staff } \\
\text { Keuangan }\end{array}$ & 4 \\
\hline $\begin{array}{c}\text { Staff } \\
\text { Operasional }\end{array}$ & 19 \\
\hline Staff audit & 4 \\
\hline $\begin{array}{c}\text { Staff } \\
\text { Marketing }\end{array}$ & 10 \\
\hline Total & 45 \\
\hline
\end{tabular}

Sumber: Arsip PT. Abadi Lestari Mandiri 2017

\section{Sampel}

Menurut Arikunto, (2012:174) sampel adalah bagian dari jumlah dan karakteristik yang dimiliki oleh populasi tersebut. Makna dari sampel yang diambil dapat mewakili bagi populasi tersebut.
Untuk sampel yang diambil dalam penelitian ini menggunakan metode sensus yang berarti semua populasi didaftar untuk menjadi sampel, dengan demikian maka yang menjadi sampel adalah semua karyawan di PT. Abadi lestari mandiri sebanyak 45 orang.

\section{Rancangan Penelitian}

Rancangan penelitian ini bersifat deskriftif kuantitatif yaitu menggambarkan pengaruh komunikasi dan budaya organisasi terhadap kinerja karyawan pada PT. Abadi lestari mandiri Palembang. Agar permasalahan tidak keluar dari konteks yang telah ditentukan, penelitian ini dibatasi pada masalah yang ada hubungannya dengan komunikasi dan budaya organisasi terhadap kinerja karyawan pada PT. Abadi lestari mandiri.

\section{Definisi Operasional Variabel}

a. Variabel Bebas (Independen), yaitu Komunikasi $\left(\mathrm{X}_{1}\right)$

Komunikasi memiliki arti yang sangat penting bagi manusia, karena tanpa komunikasi tidak akan terjadi interaksi dan tidak akan terjadi saling tukar pengetahuan dan pengalaman apalagi untuk melakukan kerja sama dalam rangka mencapai tujuan bersama. Komunikasi sangat penting bagi seluruh fungsi perusahaan, karena sistem operasional dan manajemen digerakakan oleh komunikasi (Goris, 2016).

b. Variabel Bebas (Independen), yaitu Budaya Organisasi $\left(\mathrm{X}_{2}\right)$

Variabel bebas (independent variable) yaitu budaya organisasi (X2) adalah. Menurut Emron Edison, Yohny Anwar dan Imas Komariah (2016:119) Budaya organisasi merupakan hasil dari suatu proses mencairkan dan meleburkan gaya budaya dan atau perilaku tiap individu yang dibawa sebelumnya kedalam sebuah norma-norma dan filosofi yang baru, yang memiliki energi serta kebanggaan kelompok dalam menghadapi sesuatu dan tujuan tertentu.

c. Variabel Terikat (Dependen), yaitu Kinerja (Y)

Variabel terikat (Dependent variable) yaitu kinerja karyawan (Y). Kinerja adalah hasil kerja secara kualitas dan 
kuantitas yang dicapai oleh seorang pegawai dalam melaksanakan tugasnya sesuai dengan tanggung jawab yang diberikan kepadanya Mangkunegara (2013:9)

\section{Instrument Penelitian}

Ada 2 (dua) jenis instrumen penelitian yang digunakan penulis dengan menggunakan metode uji validitas dan uji reliabilitas yaitu :

\section{Uji Validitas}

Uji validitas menunjukan ukuran yang benar-benar mengukur apa yang akan diukur. Jadi dapat dikatakan semakin tinggi validitas suatu alat test, maka alat test tersebut semakin mengenai pada sasarannya atau semakin menunjukan apa yang seharusnya diukur. Suatu test dapat dikatakan mempunyai validitas tinggi apabila test tersebut menjalankan fungsi ukurnya, atau memberikan hasil ukur sesuai dengan makna dan tujuan diadakan test tersebut.

Jika peneliti menggunakan kuesioner didalam pengumpulan data penelitian, maka item-item yang disusun pada kuesioner tersebut merupakan alat test yang harus mengukur apa yang menjadi tulisan peneliti. Salah satu cara untukk menghitung validitas suatu alat test yaitu dengan melihat daya pembeda item (item discriminality). Daya pembeda item adalah metode yang paling tepat untuk setiap jenis test. Daya pembeda item dalam penelitian ini dilakukan dengan cara korelasi item-total, mengkorelasikan masing-masing pertanyaan dengan jumlah skor masingmasing variabel. Oleh karena itu, penulis menguji tingkat validitas kuesioner yang disebarkan kepada para responden. Hasil uji validitas dengan bantuan program SPSS.

\section{Uji Reliabilitas}

Reliabilitas adalah alat untuk mengukur suatu kuisioner yang merupakan indikator suatu variabel. Uji reliabilitas adalah uji untuk memastikan apakah kuisioner penelitian yang digunakan untuk mengumpulkan data variabel penelitian reliabel atau tidak. Kuisioner dikatakan reliabel jika dilakukan pengukuran berulangulang dan akan mendapatkan hasil yang sama. Adapun cara yang digunakan untuk reliabilitas kuisioner dalam penelitian ini adalah menggunakan rumus koefisien Alpha Cronbach. Untuk mengetahui kuisioner tersebut sudah reliable akan dilakukan uji reliabilitas kueisoner dengan bantuan komputer program SPSS.

Dalam penelitian ini digunakan skala likert dengan ketentuan jawaban sangat setuju, setuju, kurang setuju, tidak setuju, sangat tidak setuju. Kelima penilaian ini untuk komunikasi, budaya organisasi dan kinerja karyawan dengan bobot sebagai berikut :

\begin{tabular}{|c|c|c|}
\hline No. & Pilihan Jawaban & Bobot \\
\hline $\mathbf{1}$ & Sangat Setuju & $\mathbf{5}$ \\
\hline $\mathbf{2}$ & Setuju & $\mathbf{4}$ \\
\hline $\mathbf{3}$ & Kurang Setuju & $\mathbf{3}$ \\
\hline $\mathbf{4}$ & Tidak Setuju & $\mathbf{2}$ \\
\hline $\mathbf{5}$ & $\begin{array}{c}\text { Sangat Tidak } \\
\text { Setuju }\end{array}$ & $\mathbf{1}$ \\
\hline
\end{tabular}

\section{Teknik Analisis Data}

\section{Uji Asumsi Klasik}

Uji asumsi klasik adalah persyaratan statistik yang harus dipenuhi pada analisis regresi linear berganda. Sebelum melakukan analisis regresi, agar dapat perkiraan yang tidak bias dan efisien maka dilakukan pengujian asumsi klasik yang harus dipenuhi.

\section{Uji Normalitas}

Uji normalitas bertujuan untuk menguji salah satu asumsi dasar analisis regresi berganda, yaitu variabel-variabel independent dan dependen harus berdistribusi normal atau mendekati normal (Ghozali, 2011:95)

Untuk melakukan uji normalitas distribusi data, peneliti menggunakan uji Kolmogrof smirnov dari program SPSS. Data dikatakan berdistribusi normal jika memiliki signifikansi $>\alpha$ ́ yang ditetapkan yaitu 0,05 .

\section{Uji Multikolinearitas}

Uji Multikolinearitas bertujuan untuk melihat ada atau tidaknya korelasi yang 
tinggi antara variabel-variabel bebas dalam suatu model regresi linear berganda. Uji multikolinearitas dilakukan dengan cara menghitung nilai Variance Inflating Factor (VIF), apabila nilai VIF tidak lebih dari 10,00 dan nilai Tolerance tidak kurang dari 0,10 maka model dapat dikatakan terbebas dari multikolinearitas (Kurniawan, 2014:54).

\section{Uji Heteroskedastisitas}

Uji Heteroskedastisitas bertujuan untuk menguji apakah dalam model regresi terjadi ketidaksamaan varians dan residual satu dengan pengamatan yang lain. Model regresi yang memenuhi persyaratan adalah dimana terdapat kesamaan varians dari residual satu pengamatan ke pengamatan yang lain tetap maka disebut homoskedastisitas dilakukan dengan menggunakan Uji Glejser dalam program SPSS, yang dilakukan dengan mengregresikan nilai absolut residual yang diperoleh dari model regresi sebagai variabel terikat terhadap variabel bebas dalam model regresi. Apabila nilai koefisien regresi dari masing-masing variabel bebas dalam model regresi ini tidak signifikan secara statistik, maka dapat disimpulkan tidak terjadi heteroskedastisitas (Kurniawan, 2014:55).

\section{Teknik Analisis Data}

Untuk analisa data, penulis menggunakan Analisis Statistik Korelasi Rank Spearman, sebab kedua variabel bersifat ordinal.Analisis statistik korelasi Rank Spearman digunakan untuk mengetahui sejauh mana hubungan antara variabel $X_{1}$ (Komunikasi), $\mathrm{X}_{2}$ (Budaya Organisasi), dengan variabel $\mathrm{Y}$ (Kinerja).

\section{Analisis Regresi Linear Berganda}

Analisis statistik yang digunakan dalam penelitian ini adalah menggunakan analisis regresi berganda dengan program SPSS. Analisis regresi berganda untukmenghitung besarnya pengaruh secara kuantitatif dari suatu perubahan kejadian (Variabel X) terhadap kejadian lainnya (Variabel Y).

Dalam penelitian ini, analisis regresi berganda berperan sebagai teknik statistik yang digunakan untuk menguji ada tidaknya pengaruh komunikasi dan budaya organisasi terhadap kinerja karyawan pada perusahaan di PT. Abadi lestari mandiri Palembang.

Analisis regresi menggunakan rumus persamaan regresi berganda yaitu :

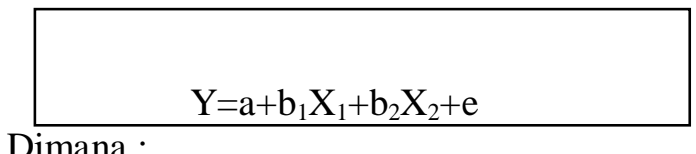

Dimana :

$\mathrm{Y}=$ Kinerja Karyawan

$\mathrm{X}_{1} \quad$ = Komunikasi

$\mathrm{X}_{2} \quad=$ Budaya Organisasi

a $\quad=$ Nilai Konstanta

$\mathrm{b}_{1,} \mathrm{~b}_{2}=$ Koefisien Regresi (berapa besar pengaruh $\mathrm{X}_{1}, \mathrm{X}_{2}$ )

$\mathrm{e} \quad=$ Kesalahan lain (merupakan bentuk variabel lainnya yang tidak diteliti oleh peneliti)

Teknik analisis ini digunakan sesuai model diatas adalah regresi berganda dimana nilai dari variabel dependen (Kinerja Karyawan) dapat diperoleh dari hasil survei yang perhitungannya menggunakan skala likert.Cara pengukurannya adalah responden diminta untuk memberikan jawaban atas pertanyaan-pertanyaan yang dianjurkan dalam kuesioner.

Prosedur diatas dipakai dengan menggunakan pedoman yang paling umum digunakan yaitu skala Likert, berhubungan dengan pernyataan tentang sikap seseorang terhadap sesuatu misalnya setuju-tidak setuju, senang-tidak senang, dan baik-tidak baik. Responden kemudian diminta mengisi pernyataan dalam skala ordinal berbentuk verbal dalam jumlah kategori tertentu.

Data yang berhasil dikumpulkan dari kuesioner selanjutnya akan diukur dengan pengukuran data ordinal dengan bobot hitung sampai 5, dengan kategori : sangat setuju dengan point 5 , setuju dengan point 4 , kurang setuju dengan point 3 , tidak setuju dengan point 2 , dan sangat tidak setuju dengan point 1.

\section{Analisis Koefisien Korelasi (r)}

Analisis koefisien korelasi adalah hubungan linear antara dua variabel atau lebih dari pengamatan untuk menguji hipotesis asosiatif (Sugiyono, 2013:248). Analisis korelasi hubungan antara komunikasi dan budaya organisasi terhadap 
kinerja karyawan menggunakan teknis analisis berganda.

\begin{tabular}{|ll|}
\hline Interval koefisien & Tingkat hubungan \\
\hline $0,00-1,99$ & Sangat lemah \\
\hline $0,199-0,399$ & Lemah \\
\hline $0,40-0,599$ & Sedang \\
\hline $0,60-0,799$ & Kuat \\
\hline $0,8-1000$ & Sangat kuat \\
\hline
\end{tabular}

\section{Analisis Koefisien Determinasi $\left(\mathbf{R}^{2}\right)$}

Analisis koefisien determinasi ini untuk mengetahui persentase pengaruh yang sudah di uji memakai uji korelasi, berikut contoh penyusunannya :

Nilai koefisien determinasi $\left(\mathrm{R}^{2}\right)$ menunjukkan presentase pengaruh semua variabel independen terhadap variabel dependen. Menjelaskan besarnya kontribusi yang diberikan variabel independen terhadap variabel dependen. Rumus koefisien determinasi dapat ditunjukkan sebagai berikut :

$$
R=\left(r^{2}\right) \times 100 \%
$$

Dimana :

$\mathrm{R}=$ Koefisien penentu atau koefisien determinasi

$\mathrm{r}^{2}=$ Koefisien korelasi

\section{Uji Hipotesis}

Seperti dijelaskan diatas uji hipotesis bertujuan untuk mengetahi hubungan antara variabel bebas terhadap variabel terikat yang akan kita teliti itu diterima atau ditolak.

1. Uji F (Uji Simultan)

Hipotesis 1 :

a. $\mathrm{H}_{0}: \mathrm{b}_{1}, \mathrm{~b}_{2}=0$, artinya tidak ada pengaruh Komunikasi dan Budaya Organisasi secara simultan (bersama-sama) terhadap Kinerja Karyawan pada PT. Abadi lestari mandiri Palembang.

b. Ha : $b_{1}, b_{2} \neq 0$, artinya terdapat pengaruh Komunikasi dan Budaya Organisasi secara simultan (bersama-sama) terhadap Kinerja Karyawan pada PT. Abadi lestari mandiri Palembang.

Kriteria Pengujian :

$\mathrm{H}_{0}$ diterima jika $\mathrm{F}$ signifikan $\geq$ 0,05

$\mathrm{H}_{0}$ ditolak jika $\mathrm{F}$ signifikan $<0,05$

Kesimpulan menerima atau menolak $\mathrm{H}_{0}$

2. Uji t (Uji Parsial)

Hipotesis 2 :

a. $\mathrm{H}_{0}: \mathrm{b}_{1}=0$, artinya tidak ada pengaruh Komunikasi terhadap Kinerja Karyawan pada PT. Abadi lestari mandiri Palembang.

b. $\mathrm{H}_{1}: \mathrm{b}_{1} \neq 0$, artinya terdapat pengaruh Budaya Organisasi terhadap Kinerja Karyawan pada PT. Abadi lestari mandiri Palembang.

Kriteria pengujian :

$\mathrm{H}_{0}$ diterima jika $\mathrm{t}$ siginifikan $\geq$ 0,05

$\mathrm{H}_{0}$ ditolak jika $\mathrm{t}$ signifikan $<0,05$

Kesimpulan menerima atau menolak $\mathrm{H}_{0}$

Hipotesis 3 :

$\mathrm{H}_{0}: \mathrm{b}_{2}=0$, artinya tidak ada pengaruh Komunikasi terhadap Kinerja Karyawan pada PT. Abadi lestari mandiri Palembang.

$\mathrm{H}_{1}: \mathrm{b}_{2} \neq 0$, artinya terdapat pengaruh Komunikasi terhadap Kinerja Karyawan pada PT. Abadi lestari mandiri Palembang.

Kriteria pengujian :

$\mathrm{H}_{0}$ diterima jika t siginifikan $\geq 0,05$

$\mathrm{H}_{0}$ ditolak jika $\mathrm{t}$ signifikan $<0,05$

Kesimpulan menerima atau menolak $\mathrm{H}_{0}$

\section{HASIL DAN PEMBAHASAN}

Pada pembahasan ini, peneliti mengemukakan analisis tenntang pengaruh komunikasi dan budaya organisasi terhadap kinerja karyawan pada PT. Abadi Lestari Mandiri Palembang. Karyawan yang merupakan responden pada PT Abadi Lestari Mandiri Palembang berjumlah 45 orang. Berikut ini adalah tabek karakteristik 
responden PT. Abadi Lestari Mandiri Palembang.

1. Tabel berikut ini menyajikan karakteristik responden berdasarkan umur dapat dilihat pada tabel berikut ini :

\section{Tabel 2. Responden Berdasarkan Usia}

\begin{tabular}{|l|c|c|}
\hline $\begin{array}{l}\text { Kelompok } \\
\text { Umur }\end{array}$ & $\begin{array}{c}\text { Jumlah } \\
\text { (orang) }\end{array}$ & Persentase \\
\hline $\begin{array}{l}20 \text { sampai } \\
\text { dengan 30 } \\
\text { tahun }\end{array}$ & 27 & $60 \%$ \\
\hline $\begin{array}{l}30 \text { sampai } \\
\text { dengan 40 } \\
\text { tahun }\end{array}$ & 14 & $31 \%$ \\
\hline $\begin{array}{l}\text { Lebih dari } \\
40 \text { tahun }\end{array}$ & 4 & $9 \%$ \\
\hline Total & 45 & $100 \%$ \\
\hline
\end{tabular}

Sumber : hasil pengolahan data

Berdasarkan tabel tersebut dapat diketahui bahwa dari 45 orang responden sebagian besar berusia lebih dari 20-30 tahun dengan pesentase sebesar $60 \%$ dari total respoden diikuti dengan golongan untuk umur 30-40 tahun yaitu sebesar $31 \%$. Sisanya adalah golongan umur lebih dari 40 tahun dengan persentase $9 \%$.

\section{Pendidikan Terakhir}

Tabel berikut ini menyajikan karakteristik responden berdasarkan pendidikan terakhir dapat dilihat pada tabel berikut ini

Tabel 3 Responden Berdasarkan Pendidikan

\begin{tabular}{|l|c|c|}
\hline \multicolumn{1}{|c|}{$\begin{array}{c}\text { Pendidikan } \\
\text { Terakhir }\end{array}$} & $\begin{array}{c}\text { Jumlah } \\
\text { (orang) }\end{array}$ & Persentase \\
\hline Sarjana (S.1) & 22 & $49 \%$ \\
\hline Sarjana (S.2) & 2 & $4 \%$ \\
\hline Diploma (D.3) & 11 & $24 \%$ \\
\hline $\begin{array}{l}\text { Sekolah } \\
\text { Menengah } \\
\text { Atas (SMA) }\end{array}$ & 6 & $13 \%$ \\
\hline $\begin{array}{l}\text { Sekolah } \\
\text { Menengah } \\
\text { Kejuruan } \\
\text { (SMK) }\end{array}$ & 4 & $9 \%$ \\
\hline Lain-lain & - & - \\
\hline Total & 45 & $100 \%$ \\
\hline
\end{tabular}

Sumber : hasil pengolahan data

Dari tabel diatas dapat diketahui bahwa frekuensi tertinggi adalah responden yang memiliki pendidikan terakhir Sarjana (S.1) sebanyak 22 orang atau 49\% kemudian berpendidikan Sarjana (S.2) sebanyak 2 orang atau 4\%, kemudian berpendidikan diploma (D.3) sebanyak 11 orang atau 24\%, kemudian berpendidikan SMA sebanyak 6 orang atau $13 \%$ dan berpendidikan SMK sebanyak 4 orang atau 9\%. Hal ini berarti mayoritas staff dan karyawan PT.Abadi Lestari mandiri Palembang memiliki latar belakang pendidikan Sarjana S1.

\section{Lama Bekerja}

Tabel berikut ini menyajikan karakteristik responden berdasarkan lama bekerja dapat dilihat pada tabel berikut ini

\section{Tabel 4 Responden Berdasarkan lama bekerja}

\begin{tabular}{|l|c|c|}
\hline $\begin{array}{c}\text { Lama } \\
\text { Bekerja } \\
\text { (Tahun/ } \\
\text { Bulan ) }\end{array}$ & $\begin{array}{c}\text { Jumlah } \\
\text { (Orang) }\end{array}$ & Persentase \\
\hline $\begin{array}{l}\text { Lebih dari } 4 \\
\text { tahun }\end{array}$ & $38 \%$ \\
\hline $\begin{array}{l}3 \text { sampai } \\
\text { dengan } 4 \\
\text { tahun sampai }\end{array}$ & 6 & $31 \%$ \\
\hline $\begin{array}{l}2 \text { san 3 } \\
\text { dengan sampai } \\
\text { tahun }\end{array}$ & 8 & $18 \%$ \\
\hline $\begin{array}{l}1 \text { dengan 2 } \\
\text { tahun }\end{array}$ & 45 orang & $100 \%$ \\
\hline Total
\end{tabular}

Sumber : hasil pengolahan data

Berdasarkan tabel diatas dapat dilihat bahwa responden yang bekerja lebih dari dari 4 tahun memiliki persentase sebanyak $38 \%$, kemudian responden yang lama bekerja 3 sampai 4 tahun memiliki persentase $31 \%$, disusul dengan karyawan yang lama bekerja 2 sampai 3 tahun dengan persentase $13 \%$ dan yang terakhir $18 \%$ untuk karyawan yang bekerja 1 sampai 2 tahun.

\section{Jabatan / pekerjaan}


Tabel 5. Responden Berdasarkan Jabatan/ Pekerjaan

\begin{tabular}{|c|c|c|}
\hline $\begin{array}{c}\text { Jabatan / } \\
\text { Pekerjaan }\end{array}$ & $\begin{array}{c}\text { Jumlah } \\
\text { (orang) }\end{array}$ & Persentase \\
\hline Direktur & 1 & $2 \%$ \\
\hline Manajer & 6 & $13 \%$ \\
\hline SPV & 11 & $24 \%$ \\
\hline Staff & 27 & $60 \%$ \\
\hline Total & 45 orang & $100 \%$ \\
\hline
\end{tabular}

Sumber : hasil pengolahan data

Berdasarkan tabel diatas dapat dilihat bahwa responden terbanyak berasal dari pekerjaan staff berjumlah 27 orang dengan persentase $60 \%$, kemudian untuk level Direktur berjumlah 1 orang dengan presentase $2 \%$, kemudian untuk level Manajer berjumlah 6 dengan presentase $13 \%$ dan yang terakhir untuk level SPV berjumlah yaitu 11 orang yaitu dengan presentase $24 \%$.

\section{Uji Validitas dan Reliabilitas}

\section{Uji Validitas}

Uji validitas dalam penelitian ini diujikan kepada 45 responden dari total Seluruh responden yaitu 45 responden. Adapun teknik pengujian dengan menggunakan SPSS 17.00 Corelation Person dengan $\mathrm{N}=45$ dan $\mathrm{r}_{\text {tabel }}=\mathrm{N}-2=43$ (tingkat kepercayaan 5\%) $=$ 0,294 . Setelah dilakukan uji validitas dengan menggunakan SPSS 17.00 Corelation Person maka hasil uji validitas instrumen pada semua variabel dalam penelitian ini dinyatakan valid karena nilai $r$ hitung pada setiap item pernyataan lebih besar atau sama dengan nilai $r_{\text {tabel. }}$ Atau $r_{\text {hitung }} \geq r_{\text {tabel }}$

Adapun hasil uji validitas selengkapnya dapat dilihat pada tabel berikut.

Tabel 6. Hasil Uji Validitas Variabel Komunikasi $\left(\mathbf{X}_{1}\right)$

\begin{tabular}{|c|c|c|c|c|}
\hline $\begin{array}{c}\text { No } \\
\text { Item }\end{array}$ & r Hitung & r Tabel & Kriteria & Keterangan \\
\hline 1 & $0,814^{* *}$ & 0,294 & $\mathrm{r}$ hitung $\geq \mathrm{r}$ tabel & Valid \\
\hline 2 & $0.929^{* *}$ & 0,294 & $\mathrm{r}$ hitung $\geq \mathrm{r}$ tabel & Valid \\
\hline 3 & $0.911^{* *}$ & 0,294 & $\mathrm{r}$ hitung $\geq \mathrm{r}$ tabel & Valid \\
\hline 4 & $0.926^{* *}$ & 0,294 & $\mathrm{r}$ hitung $\geq \mathrm{r}$ tabel & Valid \\
\hline 5 & $0.924^{* *}$ & 0,294 & $\mathrm{r}$ hitung $\geq \mathrm{r}$ tabel & Valid \\
\hline 6 & $0.944^{* *}$ & 0,294 & $\mathrm{r}$ hitung $\geq \mathrm{r}$ tabel & Valid \\
\hline 7 & $0.929^{* *}$ & 0,294 & $\mathrm{r}$ hitung $\geq \mathrm{r}$ tabel & Valid \\
\hline 8 & $0.910^{* *}$ & 0,294 & $\mathrm{r}$ hitung $\geq \mathrm{r}$ tabel & Valid \\
\hline 9 & $0.926^{* *}$ & 0,294 & $\mathrm{r}$ hitung $\geq \mathrm{r}$ tabel & Valid \\
\hline 10 & $0.899^{* *}$ & 0,294 & $\mathrm{r}$ hitung $\geq \mathrm{r}$ tabel & Valid \\
\hline
\end{tabular}

Tabel 7. Hasil Uji Validitas Variabel Budaya Orgamisasi $\left(\mathbf{X}_{2}\right)$

\begin{tabular}{|c|c|c|c|c|}
\hline $\begin{array}{c}\text { No } \\
\text { Item }\end{array}$ & r Hitung & r Tabel & Kriteria & Keterangan \\
\hline 1 & $0.957 * *$ & 0,294 & $\mathrm{r}$ hitung $\geq \mathrm{r}$ tabel & Valid \\
\hline 2 & $0.837 * *$ & 0,294 & $\mathrm{r}$ hitung $\geq \mathrm{r}$ tabel & Valid \\
\hline 3 & $0.953 * *$ & 0,294 & $\mathrm{r}$ hitung $\geq \mathrm{r}$ tabel & Valid \\
\hline 4 & $0.890^{* *}$ & 0,294 & $\mathrm{r}$ hitung $\geq \mathrm{r}$ tabel & Valid \\
\hline 5 & $0.862 * *$ & 0,294 & $\mathrm{r}$ hitung $\geq \mathrm{r}$ tabel & Valid \\
\hline 6 & $0.910^{* *}$ & 0,294 & $\mathrm{r}$ hitung $\geq \mathrm{r}$ tabel & Valid \\
\hline 7 & $0.952^{* *}$ & 0,294 & $\mathrm{r}$ hitung $\geq \mathrm{r}$ tabel & Valid \\
\hline 8 & $0.907 * *$ & 0,294 & $\mathrm{r}$ hitung $\geq \mathrm{r}$ tabel & Valid \\
\hline
\end{tabular}


Jurnal Kompetitif, Vol. 10, No. 1, hal. 67 - 84, Edisi Januari 2021

p-ISSN 2302-4585; e-ISSN 2721-3765

\begin{tabular}{|c|c|c|c|c|}
9 & $0.783^{* *}$ & 0,294 & $\mathrm{r}$ hitung $\geq \mathrm{r}$ tabel & Valid \\
\hline 10 & $0.786^{*}$ & 0,294 & $\mathrm{r}$ hitung $\geq \mathrm{r}$ tabel & Valid \\
\hline
\end{tabular}

Sumber : Hasil Pengolahan Data Menggunakan SPSS. 20.00

Tabel 8.Hasil Uji Validitas Variabel Kinerja Karyawan (Y)

\begin{tabular}{|c|c|c|c|c|}
\hline $\begin{array}{c}\text { No } \\
\text { Item }\end{array}$ & r Hitung & r Tabel & Kriteria & Keterangan \\
\hline 1 & $0.887^{* *}$ & 0,294 & $\mathrm{r}$ hitung $\geq \mathrm{r}$ tabel & Valid \\
\hline 2 & $0.888^{* *}$ & 0,294 & $\mathrm{r}$ hitung $\geq \mathrm{r}$ tabel & Valid \\
\hline 3 & $0.896^{* *}$ & 0,294 & $\mathrm{r}$ hitung $\geq \mathrm{r}$ tabel & Valid \\
\hline 4 & $0.926^{* *}$ & 0,294 & $\mathrm{r}$ hitung $\geq \mathrm{r}$ tabel & Valid \\
\hline 5 & $0.906^{* *}$ & 0,294 & $\mathrm{r}$ hitung $\geq \mathrm{r}$ tabel & Valid \\
\hline 6 & $0.875^{* *}$ & 0,294 & $\mathrm{r}$ hitung $\geq \mathrm{r}$ tabel & Valid \\
\hline 7 & $0.905^{* *}$ & 0,294 & $\mathrm{r}$ hitung $\geq \mathrm{r}$ tabel & Valid \\
\hline 8 & $0.484^{* *}$ & 0,294 & $\mathrm{r}$ hitung $\geq \mathrm{r}$ tabel & Valid \\
\hline 9 & $0.904 * *$ & 0,294 & $\mathrm{r}$ hitung $\geq \mathrm{r}$ tabel & Valid \\
\hline 10 & $0.877 * *$ & 0,294 & $\mathrm{r}$ hitung $\geq \mathrm{r}$ tabel & Valid \\
\hline 11 & $0.962^{*}$ & 0,294 & $\mathrm{r}$ hitung $\geq \mathrm{r}$ tabel & Valid \\
\hline 12 & $0.790^{* *}$ & 0,294 & $\mathrm{r}$ hitung $\geq \mathrm{r}$ tabel & Valid \\
\hline
\end{tabular}

\section{Uji Reliabilitas}

Uji reliabilitas bertujuan untuk menunjukan sejauh mana suatu hasil pengukuran relatif konsisten, apabila pengukuran diulang dua kali atau lebih. Jadi, dengan kata lain reliabilitas adalah indeks yang menunjukkan sejauhmana suatu alat pengukur dapat dipercaya atau diandalkan. Pengujian reliabilitas pada instrumen penelitian ini dengan menggunakan rumus alfa cronbach dengan menggunakan SPSS. 17.00. Scale Reability. Hasil pengujian reabilitas pada instrument penelitian ini dinyatakan reliabel karena nilai alfa dari tiap variabel di atas 0,600 . Adapun hasil pengujian dapat dilihat pada tabel berikut ini.

\section{Tabel 9. Hasil Uji Reliabilitas Komunikasi} $\left(\mathbf{X}_{1}\right)$

\section{Reliability Statistics}

\begin{tabular}{|r|r|}
\hline $\begin{array}{c}\text { Cronbach's } \\
\text { Alpha }\end{array}$ & N of Items \\
\hline .968 & 10 \\
\hline
\end{tabular}

Dari hasil analisis diatas didapat nilai cronbach alpha sebesar 0,977. Maka dapat disimpulkan bahwa butir-butir instrumen penelitian reliabel.

\section{Tabel 10. Hasil Uji Reliabilitas Budaya Organisasi $\left(\mathbf{X}_{2}\right)$}

Reliability Statistics

\begin{tabular}{|r|r|}
\hline $\begin{array}{c}\text { Cronbach's } \\
\text { Alpha }\end{array}$ & N of Items \\
\hline .968 & 10 \\
\hline
\end{tabular}

Dari hasil analisis diatas didapat nilai cronbach alpha sebesar 0,968. Maka dapat disimpulkan bahwa butir-butir instrumen penelitian reliabel.

\section{Tabel 11. Hasil Uji Reliabilitas Variabel Kinerja Karyawan (Y)}

Dari hasil analisis diatas didapat nilai cronbach alpha sebesar 0,968. Maka 
Jurnal Kompetitif, Vol. 10, No. 1, hal. 67 - 84, Edisi Januari 2021

p-ISSN 2302-4585; e-ISSN 2721-3765

dapat disimpulkan bahwa butir-butir Tabel 12. Uji Normalitas instrumen penelitian reliabel.

Uji Asumsi Klasik

Uji Normalitas

One-Sample Kolmogorov-Smirnov Test

\begin{tabular}{|ll|r|}
\hline & & $\begin{array}{r}\text { Unstandardized } \\
\text { Residual }\end{array}$ \\
\hline N & Mean & 45 \\
Normal Parameters & aE- -7 \\
& Std. Deviation & 3,40811804 \\
Most Extreme Differences & Absolute &, 133 \\
& Positive &, 133 \\
Kolmogorov-Smirnov Z & Negative &,- 116 \\
Asymp. Sig. (2-tailed) & &, 894 \\
\hline
\end{tabular}

a. Test distribution is Normal.

Uji Asumsi Klasik

b. Calculated from data.

Uji Normalitas

Tabel 13. Uji Normalitas

\begin{tabular}{|ll|r|}
\hline \multicolumn{2}{|c|}{ One-Sample Kolmogorov-Smirnov Test } \\
\hline $\mathrm{N}$ & $\begin{array}{c}\text { Unstandardized } \\
\text { Residual }\end{array}$ \\
Normal Parameters & \\
& Mean & 45 \\
& Std. Deviation & $0 \mathrm{E}-7$ \\
Most Extreme Differences & Absolute & 3,40811804 \\
& Positive &, 133 \\
Kolmogorov-Smirnov Z & Negative &, 133 \\
Asymp. Sig. (2-tailed) & &,- 116 \\
\hline
\end{tabular}

a. Test distribution is Normal.

b. Calculated from data.

Berdasarkan hasil uji normalitas

diketahui nilai signifikansi $0,400>0,05$

Uji Multikolonieritas

maka dapat disimpulkan bahwa nilai

residual berdistribusi normal.

Tabel 13. Uji Multikolonieritas

Coefficients $^{\mathrm{a}}$

\begin{tabular}{|c|c|c|c|c|c|c|c|c|}
\hline \multirow{2}{*}{\multicolumn{2}{|c|}{ Model }} & \multicolumn{2}{|c|}{ Unstandardized Coefficients } & \multirow{2}{*}{$\begin{array}{c}\text { Standardized } \\
\text { Coefficients } \\
\text { Beta }\end{array}$} & \multirow[t]{2}{*}{$\mathrm{t}$} & \multirow[t]{2}{*}{ Sig. } & \multicolumn{2}{|c|}{ Collinearity Statistics } \\
\hline & & $\mathrm{B}$ & Std. Error & & & & Tolerance & VIF \\
\hline \multirow{3}{*}{1} & (Constant) & 23,195 & 1,804 & & 12,858 & ,000 & & \\
\hline & KOMUNIKASI & ,253 & ,073 & ,328 & 3,459 &, 001 & ,620 & 1,614 \\
\hline & $\begin{array}{l}\text { BUDAYA } \\
\text { ORGANISASI }\end{array}$ &, 503 & ,075 & ,634 & 6,683 & ,000 & ,620 & 1,614 \\
\hline
\end{tabular}

a. Dependent Variable: KINERJA

Melihat nilai tolerance jika nilai tolerance lebih besar dari > 0,10 maka artinya tidak terjadi multikolonieritas. Dan dilihat dari nilai VIF lebih kecil dari< 10,00 maka artinya tidak terjadi multikolonieritas. Dilhat dari tabel diatas bahwasannya dalam penelitian ini tidak terjadi multikolonieritas.

\section{Uji Heteroskedastisitas}




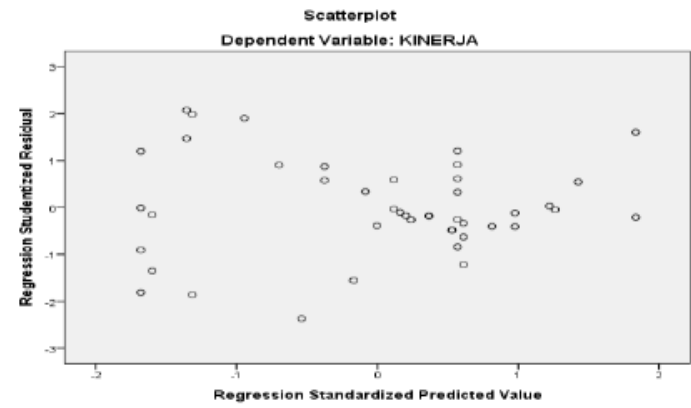

Gambar 1. Uji Heteroskedastisitas

Ciri-ciri tidak terjadi gejala Heteroskedastisitas

- Titik-titik data penyebar di atas dan di bawah atau disekitar angka 0 .

- Titik-titik tidak mengumpul hanya di atas atau di bawah saja.

Coefficients $^{a}$

\begin{tabular}{|l|r|r|r|r|r|}
\hline & \multicolumn{2}{|c|}{$\begin{array}{c}\text { Unstandardized } \\
\text { Coefficients }\end{array}$} & \multicolumn{1}{c|}{$\begin{array}{c}\text { Standardized } \\
\text { Coefficients }\end{array}$} & \\
\cline { 2 - 5 } Model & \multicolumn{1}{|c|}{$\mathrm{B}$} & Std. Error & Beta & $\mathrm{t}$ & \multicolumn{1}{c|}{ Sig. } \\
\hline $1 \quad$ (Constant) & 23,195 & 1,804 & & 12,858 &, 000 \\
KOMUNIKASI & .253 & .073 & .328 & 3,459 &, 001 \\
BUDAYA & .503 & .075 & .634 & 6,683 & .000 \\
ORGANISASI & & & & & \\
\hline
\end{tabular}

a. Dependent Variable: KINERJA KARYAWAN

Sumber : Hasil Pengolahan data dengan SPSS. 20.00

Dari hasil pengolahan data dalam program SPSS for windows versi 17.00 menunjukan bahwa nilai koefisien regresi untuk variabel Komunikasi $\left(\mathrm{X}_{1}\right)$ adalah 0,01.nilai koefisien Budaya organisasi $\left(\mathrm{X}_{2}\right)$ sebesar 0,00 dan nilai constant sebesar 23,195 Sehingga, didapatkan persamaan regresi linier berganda sebagai berikut.

$\mathrm{Y}=\alpha+\mathrm{b}_{1} \mathrm{x}_{1}+\mathrm{b}_{2} \mathrm{x}_{2}+\mathrm{e}$

$\mathrm{Y}=23,195+0,01 \mathrm{x}_{1}++0,00 \mathrm{x}_{2}+\mathrm{e}$

Dari persamaan regresi tersebut menggambarkan bahwa :

- Nilai konstanta $(\alpha)=23,195$ dapat diartikan apabila variabel Komunikasi $\left(\mathrm{X}_{1}\right)$ dan Budaya organisasi $\left(\mathrm{X}_{2}\right)$ nilainya nol, maka kinerja karyawan hanya sebesar 23,195.

- Koefisien regresi Budaya organisasi (b1) $=0,00$ menunjukkan bahwa jika
- Penyebaran titik-titik data tidak boleh membentuk pola bergelombang, melebar, kemudian menyempit dan melebar kembali.

- Penyebaran titik-titik dara tidak berpol Dari penjelasan diatas dapat disimpulkan bahwa gambar uji Heteroskedastisitas dalam penelitian ini tidak terjadinya gejala Heteroskedastisitas.

\section{Analisis Regresi Berganda}

Hasil analisis regresi berganda dengan menggunakan SPSS 20.00 pada penelitian ini dapat dilihat pada tabel berikut ini :

\section{Tabel 14. Hasil Uji Regresi Berganda}


Tabel 15. Hasil Uji Koefisien Korelasi

\section{Sederhana}

\begin{tabular}{|c|c|c|c|c|}
\hline & & KOMUNIKASI & $\begin{array}{c}\text { BUDAYA } \\
\text { ORGANISASI }\end{array}$ & KINERJA \\
\hline \multirow{3}{*}{ KOMUNIKASI } & Pearson Correlation & 1 & ,617" & ,719" \\
\hline & Sig. (2-tailed) & &, 000 & 000 \\
\hline & $\begin{array}{l}\mathrm{N} \\
\text { Pearson Correlation }\end{array}$ & $\begin{array}{r}45 \\
617^{* \pi}\end{array}$ & $\begin{array}{r}45 \\
1\end{array}$ & $\begin{array}{r}45 \\
836^{N \prime}\end{array}$ \\
\hline \multirow[t]{3}{*}{ BUDAYA ORGANISASI } & Sig. (2-tailed) & ,000 & & ,000 \\
\hline & & 45 & 45 & 45 \\
\hline & Pearson Correlation &,$/ 19$ & ,836 & 1 \\
\hline \multirow[t]{2}{*}{ KINERJA } & Sig. (2-tailed) & ,000 &, 000 & \\
\hline & $\mathrm{N}$ & 45 & 45 & 45 \\
\hline
\end{tabular}

Sumber: Hasil Pengolahan data dengan SPSS. 20.00

Dari hasil output di atas diketahui bahwa nilai korelasi antara variabel komunikasi dengan variabel kinerja karyawan sebesar 0,719 angka tersebut menunjukkan bahwa terdapat korelasi yang kuat antara variabel komunkasi dan variabel kinerja karyawan. Begitu juga nilai korelasi antara variabel budaya organisasi dengan variabel kinerja karyawan adalah sebesar 0,838 angka tersebut juga menunjukkan bahwa terdapat korelasi yang kuat antara variabel budaya organisasi dengan variabel kinerja karyawan. Apabila dilihat dari nilai signifikan dari seluruh variabel yaitu sebesar $0.000<0,05$, hal ini menunjukan bahwa terdapat korelasi antara seluruh variabel.

\section{Analisis Regresi Koefisien Determinasi}

Uji koefisien determinasi ini digunakan untuk mengetahui seberapa besar sumbangan variabel bebas, yaitu komunikasi dan budaya organisasi terhadap variabel terikat yaitu variabel Kinerja Karyawan pada PT. Abadi lestari Mandiri Palembang sebagai berikut:

Tabel 16. Hasil Uji Koefisien Determinan

\begin{tabular}{|l|c|r|r|r|}
\hline Model & $\mathrm{R}$ & $\begin{array}{c}\mathrm{R} \\
\text { Square }\end{array}$ & $\begin{array}{c}\text { Adjusted } \\
\mathrm{R} \\
\text { Square }\end{array}$ & $\begin{array}{c}\text { Std. Error of } \\
\text { the Estimate }\end{array}$ \\
\hline 1 & $.875^{\mathrm{a}}$ & .766 & .755 & 3,488 \\
\hline
\end{tabular}

a. Predictors: (Constant), BUDAYA ORGANISASI, KOMUNIKASI

Berdasarkan Tabel diatas, dapat dilihat bahwa nilai $\mathrm{R}$ Square $\left(\mathrm{R}^{2}\right)$ sebesar $0,766 \quad(76,6 \%)$ angka tersebut menggambarkan bahwa persentase sumbangan pengaruh variabel independen komunikasi dan budaya organisasi terhadap variabel dependen (kinerja karyawan) sebesar $76,6 \%$ sedangkan sisanya yaitu 23,4\% dipengaruhi oleh variabel lain yang tidak diteliti dalam penelitian ini .

\section{Uji Hipotesis}

\section{Uji F (Uji secara simultan)}

Untuk menguji variabel komunikasi $\left(\mathrm{X}_{1}\right)$,dan variabel budaya organisasi $\left(\mathrm{X}_{2}\right)$, terhadap variabel kepuasan kerja karyawan (Y) secara bersama-sama dengan menggunakan uji $\mathrm{F}$.

Tabel 17. Hasil Uji F (Uji Simultan)

\section{Model Summary}

\begin{tabular}{|l|c|r|r|r|r|}
\hline Model & $\begin{array}{c}\text { Sum of } \\
\text { Squares }\end{array}$ & \multicolumn{1}{|c|}{$\mathrm{df}$} & Mean Square & $\mathrm{F}$ & Sig. \\
\hline $1 \quad$ Regression & 1365.118 & 2 & 682.559 & 14.551 & $.000^{\mathrm{a}}$ \\
\end{tabular}




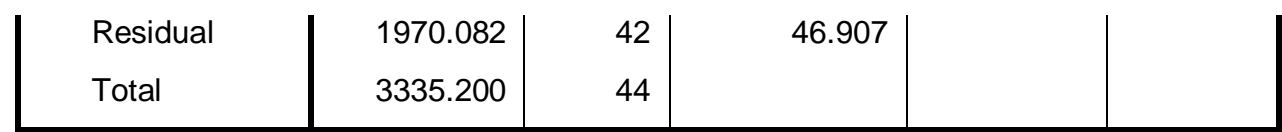

a. Predictors: (Constant), BUDAYA ORGANISASI, KOMUNIKASI

\section{3bqweer}

Sumber : rtttt790Hasil Pengolahan data dengan SPSS. 20.00

Terdapat dua cara yang bisa digunakan untuk mengetahui ada atau tidaknya pengaruh signifikan dalam uji F. Cara yang pertama. Kita dapat membandingkan antara nilai $F$ hitung dengan nilai $F$ tabel. Sedangkan cara yang kedua, kita dapat pula membandingkan nilai signifikasi atau nilai probabilitas dari hasil perhitungan SPSS apakah nilai signifikasi tersebut lebih besar atau lebih kecil dari nilai standar statistik yakni 0,05 .

- Dasar Pengambilan Keputusan dalam Uji $F$ berdasarkan nilai $F$ hitung dan F tabel

1. Jika nilai $\mathrm{F}$ hitung $>\mathrm{F}$ table maka variabel independent (bebas) secara simultan berpengaruh terhadap variabel dependent (terikat).

2. Sebaliknya,Jika nilai $\mathrm{F}$ hitung $<\mathrm{F}$ tabel maka variabel independent (bebas) secara simultan tidak berpengaruh terhadap variabel dependent (terikat).

- Dasar Pengambilan Keputusan dalam Uji $F$ berdasarkan nilai signifikansi hasil dari output SPSS

1. Jika nilai signifikansi $<0,005$, maka variabel independent secara bersama-sama berpengaruh signifikan terhadap variabel dependent.

2. Jika nilai signifikansi > 0,005, maka variabel independent secara bersama-sama tidak berpengaruh signifikan terhadap variabel dependent.

○ Interpretasi Hasil Uji F Simultan dalam Analisis Regresi

- Pengambilan Keputusan Berdasarkan nilai $\mathrm{F}$ hitung dan $\mathrm{F}$ tabel

Dari Output SPSS di atas, diperoleh nilai F hitung sebesar 14,561. Langkah selanjutnya tinggal mencari nilai $\mathrm{F}$ table dan membandingkan dengan nilai $\mathrm{F}$ hitung 14,561 .
Rumus mencari F tabel adalah :

(k: n-k)

Keterangan:

$\mathrm{k}=$ jumlah variabel Independen (bebas)

$\mathrm{n}=$ jumlah responden atau sampel penelitian

Data di atas, menunjukan bahwa $\mathrm{k}=$

2 ( $\mathrm{X}_{1}$ Komunikasi, $\mathrm{X}_{2}$ Budaya Organisasi). Dan $n=45$ Selanjutnya nilai ini akan kita masukan kedalam rumus, maka menghasilkan angka $(2: 45-2)=(2: 43)$, angka ini kemudian kita jadikan acuan untuk mengetahui nilai $\mathrm{F}$ tabel pada distribusi nilai F tabel. Diketahui bahwa nilai F tabel (2:43) adalah sebesar 3,21. Karena nilai $\mathrm{F}$ hitung 14,561 lebih besar dari nilai $\mathrm{F}$ tabel 3,21 maka dapat ditarik kesimpulan bahwa variabel bebas X1 (Komunikasi) dan X2 (Budaya Organisasi Secara simultan berpengaruh terhadap variabel terikat $\mathrm{Y}$ ( Kinerja Karyawan).

- Pengambilan Keputusan dalam uji F berdasarkan Nilai Signifikansi

Dari output SPSS diatas, diketahui nilai signifikansi sebesar 0,000 . Karena nilai signifikansi $0,000<(\alpha) 0,05$ sesuai dengan dasar pengambilan keputusan dalam uji $\mathrm{F}$ maka dapat disimpulkan pula bahwa komunikasi $\left(\mathrm{X}_{1}\right)$ dan budaya organisasi $\left(\mathrm{X}_{2}\right)$ (Secara Simultan) berpengaruh terhadap kinerja karyawan $(\mathrm{Y})$.

Dengan melihat penjabaran diatas, maka pengambilan keputusan dalam uji $\mathrm{F}$ baik itu membandingkan nilai $\mathrm{F}$ hitung dengan $\mathrm{F}$ table, maupun berpedoman pada nilai signifikansi diperoleh hasil yang sama pula atau hasil yang konsisten.

\section{Uji t (Uji parsial)}

Uji t dikenal dengan uji parsial, yaitu untuk menguji bagaimana pengaruh masing-masing variabel bebasnya secara sendiri-sendiri terhadap variabel terikatnya. Uji ini dapat dilakukan dengan membandingkan $t$ hitung dengan tabel. Atau dengan melihat kolom 
signifikansi pada masing-masing $\mathrm{t}$ hitung. Untuk menguji variabel komunikasi $\left(\mathrm{X}_{1}\right)$, variabel budaya organisasi $\left(\mathrm{X}_{2}\right)$, terhadap variabel kinerja karyawan (Y) secara satu-satu dengan menggunakan uji T.

\section{Tabel 18. Hasil Uji t (Parsial)}

\begin{tabular}{|c|c|c|c|c|c|c|}
\hline \multirow[b]{2}{*}{ Model } & & \multicolumn{2}{|c|}{$\begin{array}{c}\text { Unstandardized } \\
\text { Coefficients }\end{array}$} & \multirow{2}{*}{$\begin{array}{c}\begin{array}{c}\text { Standardized } \\
\text { Coefficients }\end{array} \\
\text { Beta }\end{array}$} & \multirow[b]{2}{*}{$t$} & \multirow[b]{2}{*}{ Sig. } \\
\hline & & $\mathrm{B}$ & Std. Error & & & \\
\hline \multirow{3}{*}{$\begin{array}{l}\text { (Constant) } \\
\text { KOMUNIKASI } \\
\text { BUDAYA } \\
\text { ORGANISASI }\end{array}$} & 40.819 & 23,195 & 1,804 & & 12,858 &, 000 \\
\hline & .806 & 253, & ,073 & 328, & 3,459 & ,001 \\
\hline & .559 & 503, & ,075 & 634, & 6,683 & ,000 \\
\hline
\end{tabular}

a. Dependent Variable: KINERJA KARYAWAN

Sumber : Hasil Pengolahan data dengan SPSS. 20.00

- Ada dua dasar pengambilan keputusan untuk uji T parsial dalam Analisis Regresi

- Berdasarkan nilai T hitung dan $T$ tabel

1. Jika nilai $t$ hitung $>t$ tabel maka variabel bebas berpengaruh terhadap variabel terikat

2. Jika nilai $\mathrm{t}$ hitung $<t$ tabel maka variabel bebas tidak berpengaruh terhadap variabel terikat

- Berdasarkan nilai signifikansi hasil output SPSS

1. Jika nilai Sig. < 0,05 maka variabel bebas berpengaruh signifikan terhadap variabel terikat.

2. Jika nilai Sig. > 0,05 maka variabel bebas tidak berpengaruh signifikan terhadap variabel terikat.

Dengan melihat output di atas berarti terdapat dua hipotesis $\left[\mathrm{H}_{\mathrm{a}}\right]$ yang diajukan dalam uji t ini :

1. $\mathrm{H}_{1}=$ Komunikasi $\left(\mathrm{X}_{1}\right)$ berpengaruh signifikan terhadap Kinerja Karyawan $(\mathrm{Y})$ - [disebut uji t pertama]

2. $\mathrm{H}_{2}=$ Budaya Organisasi $\left(\mathrm{X}_{2}\right)$ berpengaruh signifikan terhadap Kinerja Karyawan $(\mathrm{Y})$ - [disebut uji T kedua]

- Cara Melakukan uji t parsial [ uji $t$ pertama]

Berdasarkan output SPSS

Coefficients di atas, diketahui bahwa

nilai koefisien regresi variabel
Komunikasi $\left(\mathrm{X}_{1}\right)$ adalah sebesar 0,253 bernilai positif (+), sehingga dapat dikatakan bahwa Komunikasi $\left(\mathrm{X}_{1}\right)$ berpegaruh positif terhadap Kinerja Karyawan (Y). Pengaruh positif diartikan, bahwa semakin meningkat Komunikasi $\left(X_{1}\right)$ maka akan meningkat pula Kinerja Karyawan (Y).

Selanjutnya, untuk mengetahui apakah pengaruh tersebut signifikan atau tidak, maka nilai koefisien regresi dari variabel Komunikasi $\left(\mathrm{X}_{1}\right)$ ini akan diuji signifikasinya inilah yang sering disebut dengan uji $t$ parsial dalam analisis regresi.

- Hipotesis (Dugaan) dalam uji t pertama adalah :

1. Ho $=$ Komunikasi $\left(\mathrm{X}_{1}\right)$ tidak berpengaruh signifikan terhadap Kinerja Karyawan (Y)

2. $\mathrm{H}_{1}=$ Komunikasi $\left(\mathrm{X}_{1}\right)$ berpengaruh signifikan terhadap Kinerja Karyawan (Y)

Tingkat kepercayaan yang digunakan adalah $95 \%$, maka nilai $\alpha=0,05$

- Dasar Pengambilan Keputusan dalam Uji t pertama

1. Ho diterima dan $\mathrm{H}_{1}$ ditolak jika nilai $\mathrm{t}$ hitung $<\mathrm{t}$ tabel atau jika nilai Sig. $>0,05$ 
2. Ho ditolak dan $\mathrm{H}_{1}$ diterima jika nilai $\mathrm{t}$ hitung $>\mathrm{t}$ table atau nilai Sig. $<0,05$

Rumus untuk mencari Nilai t table adalah :

$\mathrm{t}$ tabel $=(\alpha / 2 ; \mathrm{n}-\mathrm{k}-1)$

ket :

$\alpha=$ tingkat kepercayaan

$\mathrm{n}=$ jumlah responden

$\mathrm{k}=$ jumlah variabel bebas

jadi :

$\mathrm{t}$ tabel $=(\alpha / 2 ; \mathrm{n}-\mathrm{k}-1)$

$\mathrm{t}$ tabel $=(0,05 / 2 ; 45-2-1)$

$\mathrm{t}$ tabel $=(0,025 ; 45-2-1)$

$\mathrm{t}$ tabel $=(0,025 ; 42)$

$\mathrm{t}$ tabel $=$ angka 0,$025 ; 42$ kemudian di cari pada distribusi nilai $\mathrm{t}$ tabel maka nilai $\mathrm{t}$ tersebut adalah sebesar. 2,01808

- Hasil dan pengambilan keputusan dalam uji t Pertama :

Berdasarkan hasil analisis regresi di peroleh nilai t hitung sebesar 3,056 > t tabel 2,01808 dan nilai signifikansi (Sig.) $0,000<0,05$. Maka dapat disimpulkan bahwa Ho ditolak dan $\mathrm{H}_{1}$ diterima, yang artinya Komunikasi $\left(\mathrm{X}_{1}\right)$ berpengaruh signifikan terhadap Kinerja Karyawan (Y)

- Cara Melakukan uji t parsial [ uji t kedua]

Untuk uji $\mathrm{t}$ kedua yakni dengan $\mathrm{H}_{2}=$ budaya organisasi $\left(\mathrm{X}_{2}\right)$ berpengaruh signifikan terhadap kinerja karyawan (Y). Berdasarkan output SPSS Coefficients di atas, diketahui bahwa nilai koefisien regresi variabel budaya organisasi $\left(\mathrm{X}_{2}\right)$ adalah sebesar 0,503 bernilai positif (+), sehingga dapat dikatakan bahwa budaya organisasi $\left(\mathrm{X}_{2}\right)$ berpegaruh positif terhadap kinerja karyawan (Y). Pengaruh positif diartikan, bahwa semakin meningkat budaya organisasi $\left(\mathrm{X}_{2}\right)$ maka akan meningkat pula kinerja karyawan $(\mathrm{Y})$.

Hipotesis (Dugaan) dalam uji t kedua adalah :

1. $\mathrm{Ho}=$ Budaya organisasi $\left(\mathrm{X}_{2}\right)$ tidak berpengaruh signifikan terhadap kinerja karyawan (Y)
2. $\mathrm{H}_{2}=$ Budaya organisasi $\left(\mathrm{X}_{2}\right)$ berpengaruh signifikan terhadap kinerja karyawan (Y)

Tingkat kepercayaan yang digunakan adalah $95 \%$, maka nilai $\alpha=0,05$

- Dasar Pengambilan Keputusan dalam Uji t kedua

1. Ho diterima dan $\mathrm{H}_{2}$ ditolak jika nilai $\mathrm{t}$ hitung $<\mathrm{t}$ tabel atau jika nilai Sig. $>0,05$

2. $\mathrm{H} 0$ ditolak dan $\mathrm{H}_{2}$ diterima jika nilai $\mathrm{t}$ hitung $>t$ tabel atau nilai Sig. $<0,05$

- Hasil dan pengambilan Keputusan dalam uji t Kedua :

Berdasarkan hasil analisis regresi di peroleh nilai t hitung sebesar 3,137 > t tabel 2,01808 dan nilai signifikansi (Sig.) $0,03<0,05$. Maka dapat disimpulkan bahwa Ho ditolak dan $\mathrm{H}_{2}$ diterima, yang artinya budaya organisasi $\left(\mathrm{X}_{2}\right)$ berpengaruh signifikan terhadap kinerja karyawan (Y)

\section{SIMPULAN DAN SARAN}

\section{Simpulan}

Berdasarkan data hasil penelitian yang telah diolah dan dianalisis, maka dapat diambil kesimpulan sebagai berikut :

1. Berdasarkan pengujian simultan dengan nilai $\mathrm{F}$ hitung sebesar $(14,551 \%>$ sig 0,05 ) diketahui bahwa komunikasi dan budaya organisasi secara bersama-sama memberikan pengaruh positif dan signifikan terhadap kinerja karyawan PT. Abadi Lestari Mandiri Palembang.

2. Berdasarkan pengujian hipotesis variabel komunikasi memberikan pengaruh yang positif dan signifikan dengan nilai sebesar $0,719 \%$ terhadap kinerja karyawan PT. Abadi Lestari Mandiri Palembang.

3 Berdasarkan pengujian hipotesis variabel budaya organisasi memberikan pengaruh yang positif dan signifikan dengan nilai sebesar $0,836 \%$ terhadap kinerja karyawan PT. Abadi Lestari Mandiri Palembang.

\section{Saran}

Berdasarkan hasil dari penelitian yang telah diuraikan, peneliti mencoba memberikan saran sebagai berikut :

1. Variabel komunikasi lebih berpengaruh terhadap kinerja karyawan, maka 
disarankan agar perusahaan dapat mempertahankannya atau bahkan meningkatkan variabel tersebut. Agar karyawan dapat bekerja secara baik (efektif dan efisien)

2. Walaupun variabel budaya organisasi tidak begitu berpengaruh terhadap Kinerja Karyawan, Tetapi budaya organisasi juga perlu ditingkatkan, Karena dengan adanya budaya organisasi setiap pekerjaan yang kita lakukan bisa jauh lebih baik.

3. Bagi penelitian selanjutnya agar mempertimbangkan atau menambah variabel lain yang mempengaruhi kinerja karyawan. Jika perlu penelitian yang selanjutnya menambah jumlah kuesioner yang disebarkan agar data yang didapat lebih banyak untuk diteliti. Sehingga memungkinkan hasil yang komprehensif.

\section{E. DAFTAR RUJUKAN}

AA. Anwar Prabu Mangkunegara, 2013, Manajemen Sumber Daya Manusia Perusahaan. Bandung: Remaja Rosdakarya.

Albert Kurniawan. 2014. Metode Riset untuk Ekonomi dan Bisnis. Bandung: CV Alfabeta.

Arikunto, Suharsimi. (2012). Prosedur Penelitian Suatu Pendekatan Praktek. Jakarta: Rineka Cipta

AW Suranto, 2011. Komunikasi Interpersonal. Yogyakarta: Graha Ilmu.

Edison, Emron. Yohny anwar, Imas komariyah. 2016. Manajemen Sumber Daya Manusia. Bandung: Alfabeta.

Mulyana, Deddy. 2013. Ilmu Komunikasi: Suatu Pengantar. Bandung: Remaja Rosdakarya.

Schein, Edgar H. 2014. Organizational Culture and Leadership. San Francisco: Josey-Bass Publishers.

Sugiyono. 2013. Metode Penelitian Pendidikan Pendekatan Kuantitatif, Kualitatif, dan R\&D. Bandung: Alfabeta.

Rivai, Veithzal. 2014. Manajemen Sumber Daya Manusia untuk Perusahaan,
Edisi ke 6, PT. Raja Grafindo Persada, Depok. 